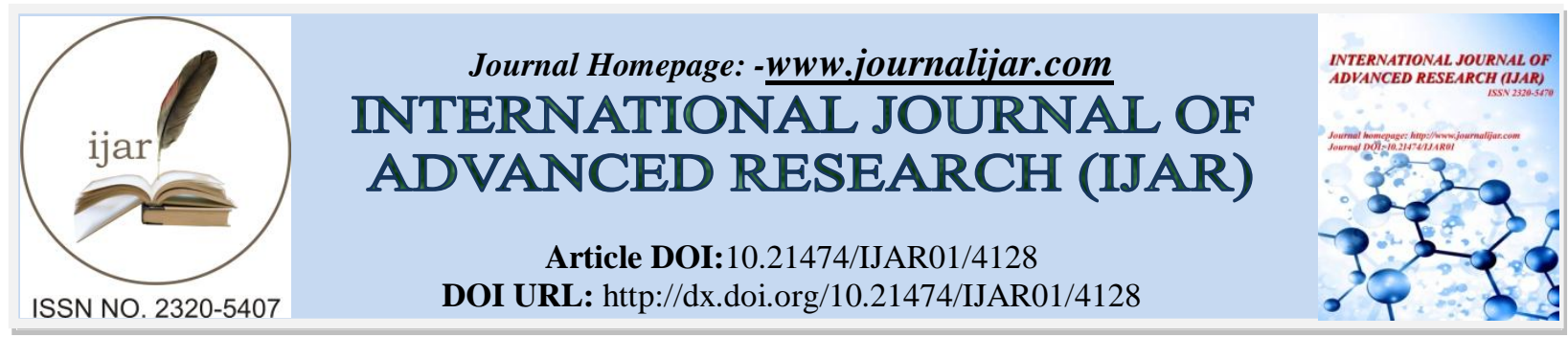

RESEARCH ARTICLE

\title{
GREEN ECONOMY: BY HUMANS, FOR HUMANS.
}

Lu Zhibo, Craig Sturrock.

Environmental Ethics, College of Environmental Science and Engineering,Tongji University, Shanghai, China, 200092.

\section{Manuscript Info}

Manuscript History

Received: 05 March 2017

Final Accepted: 03 April 2017

Published: May 2017

\begin{abstract}
This paper aims to critically analyse the axiomatic assumption of Green Economy providing a space for environmental ethics as a path to sustainable development. The paper begins by discussing the relationship between sustainable development and ethics by asserting that an economic paradigm is able to determine individual and organisational value systems resulting in ethical perspectives. From this theory, the paper defines and discusses both traditional ethics (utilitarianism and deontology) and environmental ethics (eco-centrism and deep ecology) respectively to neo-classical and ecological economic paradigms distinguishing between instrumental and intrinsic value. Reiterating that value is a crucial decisive factor in determining ethical perspective, the text discusses this with relation to the Green Economy paradigm. Conclusions reveal that Green Economy, although recognizing nature and its intrinsic value somewhat, is purely anthropocentric in its approach and leaves little room for an environmental ethical perspective by definition of environmental ethical theories as it conserves nature for current and future human generations and not for nature itself.
\end{abstract}

Copy Right, IJAR, 2017,. All rights reserved.

\section{Introduction:-}

Within today's current economic climate, the environment and the eco services it provides to human welfare is evidently the victim of exploitation. The current market-based economic paradigm, especially within a globalized context, is one that is conducive to environmental degradation and decline with the neglect of any application of environmental ethics. Given the future outlook of climate change, population growth and utilitarian consumption patterns combined with constrained availability of the earth's finite natural resources, economic models and policies play a pivotal role in the mitigation of environmental issues.

An example of an economic approach that encompasses sustainable development and growth while reducing environmental damage is the green economy initiative. UNEP (2010) defines a Green Economy as one that results in "improved human well-being and social equity, while significantly reducing environmental risks and ecological scarcities". To put it simply, a green economy is socially inclusive, resource efficient with low-carbon emissions (UNEP, 2011).

It is implicit green economy transitions aim to benefit the greater good not to mention highlighting environmental protection is also a "good" thing for society and the environment. However, when discussing these issues from an 
ethical perspective, it is important to define the difference between common ethics and environmental ethics and which economic paradigm serves which ethical theory.

It can be easily mistaken when discussing Green Economy to automatically assume that this economic paradigm takes a wholly eco-centric approach, however when breaking down definitions, theories and practices of ethics, economics and sustainability it becomes clear that anthropocentric values take precedence. The aim of this literature is not to discredit Green Economy transitions. Rather, the paper aims to demonstrate explicitly the ethical principles and value sets that apply to Green Economy in comparison to current economic paradigms as a path to sustainable development. Moreover, the text will discuss whether the green economic paradigm can support environmental ethical principles effectively in the course of global sustainable development.

In order to determine whether Green Economy and environmental ethics can coexist in harmony, it is imperative to investigate and define both "green" and "brown" economic paradigms as well as ethical theories and principles and the values and morals that predetermine them.

\section{Sustainable Development and Ethics:-}

The notion of sustainable development was coined in the Brundtland report (1987). A problematic issue for sustainable development is its broad definition and how governments, industries and individuals interpret it. In terms of economic development, it stresses the importance of environmental quality and the conservation of Nature's assets (World Commission on Environment and Development 1987; Pearce, Markandya and Barbier, 1989; Turner, 1988; Barbier, Markandya and Pearce, 1990; Pearce and Turner, 1990). If utilizing this definition, it can be implied that sustainable development takes an environmental ethical approach. However, the definition that is most commonly used and serves the most benefit of this text is "development that meets the needs of the present without compromising the ability of future generations to meet their own needs" (WCED, 1987). When using this definition however, it seems to take a more anthropocentric approach to ethical theory and application. The reason of this definition's importance is to explore it in relation to environmental economics, human ecology and ethics as highlighted in Figure 1.

It is clear from figure 1 (Turner and Pearce, 1993), there is direct link between ethical principles and values in determining the level of sustainable development.Amongst others, this is dependent on two interrelated points. A) How an individual or organization perceive the notion of sustainable development and value the environment, and B) The economic paradigm used determines the ethical theory and principles applied. For example, from an environmental economic perspective the individual places value on the environment determining its utility and the amount of "good" it delivers which is conducive to anthropocentric ethical principles, resulting in weak sustainability with little to no account for intergenerational equity. Whereas, ecological economics presents a more collective and interdisciplinary value system acknowledging the environment has intrinsic value resulting in an environmental ethical perspective with the outcome of strong sustainability and recognition for intergenerational equity. 
Figure 1:- Development of environmental ecological economics.

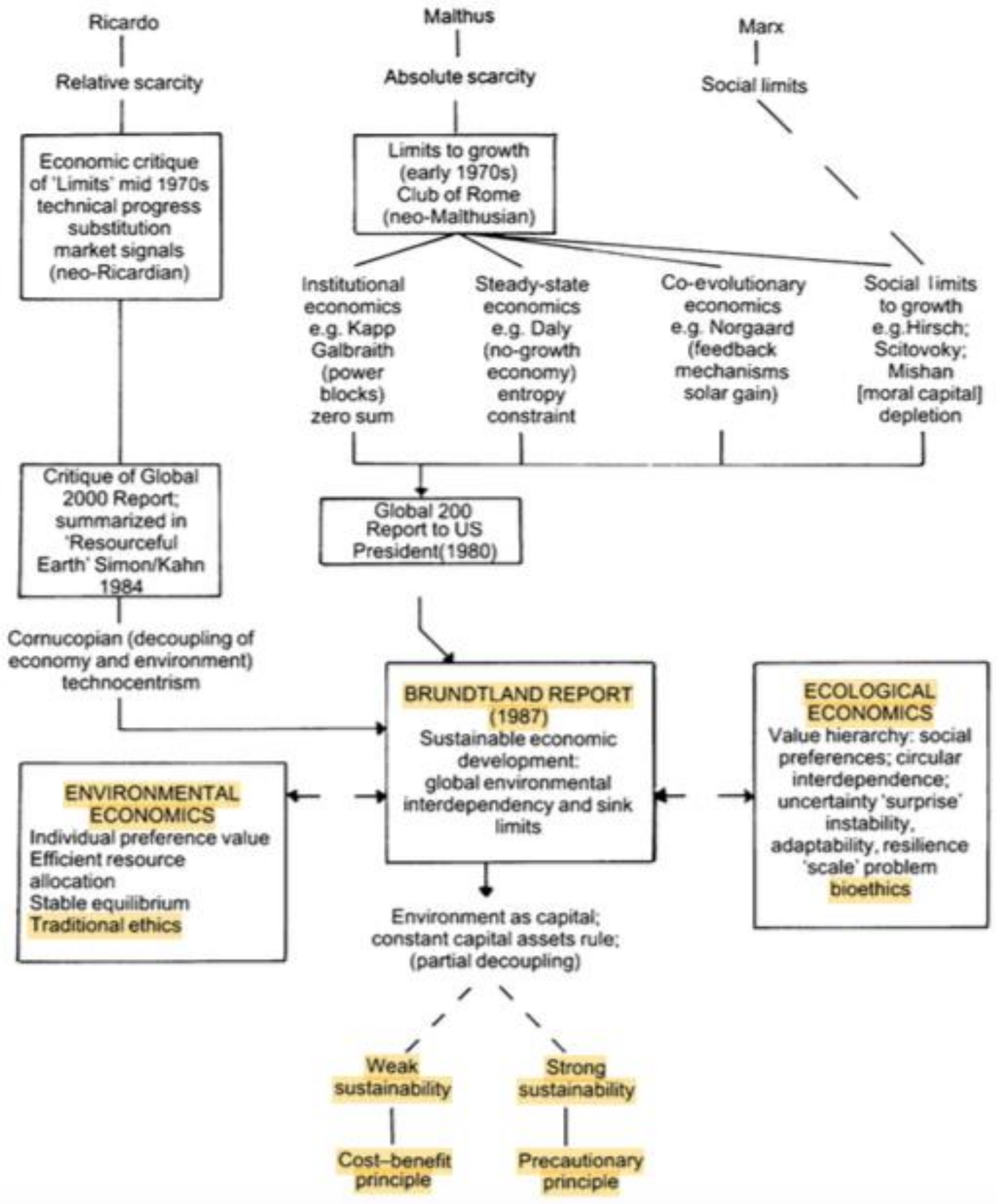

Source: Adapted from Turner and Pearce, 1993.

\section{Ethical Definitions:-}

When discussing ethics it is important to differentiate between common ethics and environmental ethics, and the theories that apply to them. In its simplest form, ethics can be described as dealing with what is morally good and bad. In other words, a general idea or belief that directs or influences people's behaviour and attitudes (Yongsen, 2015). Anthropocentric in nature, common or traditional ethics can have many applied theories. 
One that will be of primary concern is the theory of Utilitarianism. Zhang (2015) describes utilitarianism as telling us to maximise the overall good. If the act tends to maximise good consequences, it is an ethically right act, and if it does not, it is ethically wrong. Utilitarianism can be viewed from either a group of people or community, such as governments and corporate entities or from an individual perspective. For example, utilitarianism from a government point of view can be used to influence policy. If the policy initiative serves to maximise the overall good for the greater number of citizens then the policy is considered a "good" thing. From an individual perspective, utilitarianism is perceived in terms of self-interest and wellbeing. It is important to note that individual utility is a main market-based tool in economics to determine supply and demand.

Deontology is also an ethical theory that will be useful to the literature. Deontology emphasizes the notion of acting on principle rather than in terms of consequences, the central concepts being duties and rights. Deontology claims that we can be held responsible only for those things that we can control. For example, the principle of justice requires us to fulfil our duties to other people, and justice requires we respect the rights of others at all times and under all conditions. By contrast to Utilitarianism in which it requires us to fulfil or duties and respect others' rights only when doing so maximizes the overall good consequences (Zhang, 2015). In the case of sustainable development and inter-generational equity deontology would state that future generations have rights, where as utilitarianism would be concerned with maximizing the happiness of the greater good in the present.

Environmental ethics is another disciple of the ethics family and its primary focus is that of the relationship between human beings and nature (Buzzle, 2011).In contrast to common ethics, environmental ethics is more nonanthropocentric in its approach. To put it simply, anthropocentric is human centred, meaning that humans are the sole bearer of intrinsic value and all other living things are there to sustain humanity's existence (MacKinnon, 2007, p. 331). Non-anthropocentric or eco-centrism is non-human centred and recognizes a nature-centred system of values, and extends the inherent worth to all living things regardless of their usefulness to humans(MacKinnon, 2007, p. 336). Theories that relate to environmental ethics such as eco-centrism and deep ecology are able to better explain the differentiation of the two ethics camps.

The theory of deep ecology is one that can be used as a "middle-ground" reasoning between the conflicts of anthropocentrism and eco-centrism. According to George Sessions and Arne Naess's (coiner of the term Deep Ecology in Naess 1973) basic principles of deep ecology encompass both anthropocentric and eco-centric reasoning by acknowledging intrinsic value in all nature's beings and allowing for consuming species to benefit from what the environment offers to fulfil vital needs. To put it simply, it allows consumption of nature's resources for the sake of needs rather than explicit wants or luxuries.

\section{Economic Paradigms:-}

As we briefly discussed in figure 1, in order to differentiate if an economic paradigm, namely brown or green economic paradigms can coincide with theories of environmental ethics; the text will explore the current marketbased neo-classical paradigm as well as the theory of Green Economy transitions (Ecological Economics). Moreover, it is important to define the broad terms used such as economy, green or brown, to contextualise ethical principles and theories as well as determine sustainable development with economics and ethics respectively.

It can be stated that neo-classical economics or market-based economic approachesare firmly rooted in the ethical philosophy of utilitarianism. Coined by English Philosopher Jeremy Bentham in the late eighteenth century (17481832), it proposed that government policy should maximise the 'greatest happiness of the greatest number' (Blowers and Hinchcliffe, 2003). From an individual perspective utilitarianism is a case of self-interest and utility of the goods being used, determining value of the goods as a market-based tool.

There are, in environmental economics, two distinct though sometimes overlapping camps. On the one hand, there are neo-classical economists who study environmental issues from the perspectives of efficiency and growth. However, there is a second group called ecological economists, who emphasise the importance of institutions in determining outcomes. They tend to be concerned with social and environmental consequences of economic activity and use relatively little mathematics in their analysis. In addition, they tend to be on the side of conservation and local self-management rather than big business and the maximization of profit.

Three key differences between ecological economics and neo-classical environmental economics are summarized in table 1. Firstly, ecological economics tend to give more emphasis to the scale of economic activity and its impact on 
environments. The neo-classical approach tends to view the environment as a source of inputs and then ask how these inputs might best be exploited (Blowers and Hinchcliffe, 2003). The ecological approach however, seeks to emphasize other issues such as the links between human well-being and the natural environment as well as our duty to respect and value the environment for its own sake. Related to this is a second issue to do with substitutability of resources, which is related to the optimism/pessimism debate. Neo-classical economics tends to assume that innovation will allow other inputs to be substituted for the environmental resources that are permanently depleted, while ecological economists are more sceptical about this possibility (Blowers and Hinchcliffe, 2003). Finally, and again linked to the previous points, there is a difference between the two schools of environmental economics in the extent to which they believe that human well-being is dependent on the environment (Dawson, 2003). Neo-classical economists tend to see the link being reduced while ecological economists believe human well-being is ultimately related to the status of the environment. Table 1 adapted from Turner (1994) summarises some of the differences between these two schools of thought.

Table 1:- Ecological economics and neo-classical environmental economics compared

\begin{tabular}{|l|l|l|}
\hline & $\begin{array}{l}\text { Neo-classical environmental } \\
\text { Economics }\end{array}$ & Ecological Economics \\
\hline Amount of economic activity & $\begin{array}{l}\text { There is a modest interest in the } \\
\text { relationship between the amount of } \\
\text { economic activity and its impact on } \\
\text { the global environment }\end{array}$ & $\begin{array}{l}\text { Considerable concern for the impact } \\
\text { of economic activity }\end{array}$ \\
\hline Substitution between inputs & $\begin{array}{l}\text { Human-made capital can be } \\
\text { substituted for natural capital if } \\
\text { depleted will be difficult to find human- } \\
\text { made substitutes for some natural } \\
\text { resources }\end{array}$ \\
\hline $\begin{array}{l}\text { Links between economy and } \\
\text { ecological welfare }\end{array}$ & $\begin{array}{l}\text { Economic growth is increasingly } \\
\text { unrelated to the status of the } \\
\text { environment }\end{array}$ & $\begin{array}{l}\text { Economic and ecological welfare are } \\
\text { closely coupled }\end{array}$ \\
\hline
\end{tabular}

Source: Adapted from Turner, 1994.

Values:-

The key aim for a transition to a green economy is to enable economic growth and investment while increasing environmental quality and social inclusiveness (UNEP, 2011). In order to achieve such factors, main indicators of economic performance such as, Gross Domestic Product (GDP) need adjustment to account for resource depletion, declining ecosystem services among others (UNEP, 2011). Essentially, this indicator adjustment requires giving nature and the services it provide an economic value.

However, a contrary perspective is evident within the current economic paradigm, that being, a disregard for the value of environmental and ecosystem services provided altogether. Such eco-system services can be referred to as externalities. Thus, if the services the environment provides for human welfare are imperative to development, growth and survival, then the question is of value.

From an economic standpoint, how much of the environment needs to be conserved? What is nature's value? From an ethical standpoint, do current economic structures play a role in environmental ethics? And more importantly, does the transition to green economy play a role in "effectively" applying environmental ethics?

In answer to the question of value and environmental responsibility, conventional economics phrase the answer in terms of human individual preferences for particular things that possess instrumental value to the extent that some individual is willing to pay for the satisfaction of a preference (Turner, 1999). Rooted in this approach is the axiomatic assumption that individuals mainly make choices that benefit self interest or enhance their welfare (Turner, 1999). Applying a cost-benefit approach, economists argue that nature conservation benefits should be valued and compared with their relevant costs. Therefore, conservation measures should only be adopted if it can be demonstrated that they generate net economic benefits.

From an environmentalist perspective however, the question of the value of nature takes a different approach. They either claim that nature has non-anthropocentric intrinsic value and non-human species possess moral interest or rights, or that while all values are anthropocentric and usually instrumental the economic approach to environmental valuation is only a partial approach (Hargrove, 1992). 
The two approaches mentioned above, indicates evidently,there is a clear difference in how nature is valued depending on how individuals perceive nature and how nature's intrinsic or instrumental value serve them directly. Table 2 defines the value differences from an economist's standpoint, i.e. the instrumental value of nature taking precedence in individual satisfaction and utility and an environmentalist's standpoint stresses the importance of nature in its intrinsic value and how it serves human welfare.

Table 2:- Value differences between Anthropocentrism and Eco-centrism

\begin{tabular}{|l|l|}
\hline $\begin{array}{l}\text { Anthropocentrism } \\
\text { Instrumental Value }\end{array}$ & Non-Anthropocentric (Eco-centrism) Intrinsic Value \\
\hline Defining Features & $\begin{array}{l}\text { Humans are members of the biotic } \\
\text { community }\end{array}$ \\
\hline $\begin{array}{l}\text { Humans are managed of the } \\
\text { Ethical principles }\end{array}$ & $\begin{array}{l}\text { Good of the biotic community defines } \\
\text { Adequate ethical principles }\end{array}$ \\
\hline $\begin{array}{l}\text { Humans are ethically prioritized, } \\
\text { But there is a limit to what extent environmental damage } \\
\text { is justifi }\end{array}$ & $\begin{array}{l}\text { Humans have no prerogative to use environmental in a } \\
\text { way that hinders the flourishing of other species }\end{array}$ \\
\hline $\begin{array}{l}\text { Environment is valued for its value to humans (yet, the } \\
\text { value may be other than instrumental) }\end{array}$ & $\begin{array}{l}\text { Life forms and ecosystems are valued in themselves, } \\
\text { regardless of their value to humans }\end{array}$ \\
\hline $\begin{array}{l}\text { Brundtlandian definition of sustainability involving only } \\
\text { human generations }\end{array}$ & $\begin{array}{l}\text { Notion of sustainability involves other life forms and } \\
\text { whole ecosystems }\end{array}$ \\
\hline
\end{tabular}

Source: Adapted from Kortetmäki, 2013

\section{Discussion:-}

It is evident thus far, that an economic paradigm can act as a catalyst for ethical positioning, whether it be traditional or environmental ethics. Moreover, the economic paradigm as well as the ethical perspectives is also determining factors in the level of sustainable development that is valued and applied.

As mentioned previously, there is a direct link between values and ethical camps that ultimately determines the value and level in application of sustainable development. For example, in figure 1 it highlights that over the past decades of dialogue in environmental issues and scarcity in relation to economic development. The economic paradigm used at local, regional and global levels determine an individual and/or organisational value set conducive to ethical camp and theory, determining weak or strong sustainability application.

Environmental economics or neo-classical market-based economies are rooted in the theory of utilitarianism and individual preference value resulting in a traditional or anthropocentric ethical perspective, allowing for high levels of instrumental value for the environment and its services. Whereas, ecological economic paradigms encourage more eco-centric values and acceptance of the importance of the environment to human well-being and the willingness to pay for externalities and eco-system services. This value set therefore is conducive to an environmental ethical perspective, resulting in strong sustainability application. From this analysis, we can safely assume in-order for there to be a shift in value systems and ethical positioning that is aligned with the values of the environment a shift in economic paradigms is necessary and Green Economy transitions and ecological economics appears to be a viable option.

However, there seems to be controversy and unanswered questions surround the Green Economy approach, especially its possibilities and limitations in bio-diversity conservation. Regarding nature, the main proposition of the Green Economy is that it will significantly reduce environmental risk and impacts by promoting the efficient and sustainable use of natural resources (UNEP, 2011). Many of the specific tools to achieve that goal derive from environmental economics, which considers nature as fragmented and divided into "natural resources" or environmental "goods" or "services"; nature is seen as another form of capital: "Natural Capital" (Ghione and Gudynas, 2012).

There are several problems with this understanding of nature, among them, a tendency to confuse economic value with the "real" value of nature. This is also the central aim of neo-liberal market-based conservation, which relies on the assumption that biodiversity's non-monetised values are deemed insufficient to preserve it (Irvine, 2011). 
Furthermore, the Green Economy approach considers that valuing natural capital in economic terms is the way to indicate its importance for sustaining human and economic prosperity (UNEP, 2011). Thus, the conservation of nature will only be ensured if we are able to incorporate it into profitable economic processes, in which nature becomes another form of capital.

Green Economy is heavily dependent on a market-based approach economic approach. The most cited environmental economic tool is the use of Payment for Ecosystem Services (PES), which is defined as a voluntary transaction of an ecosystem service (ES) among a byer and a seller of the ES, which must secure the ES provision. The schemes are presented as new conservation paradigms. However, there is still a lack of good evidence confirming PES effects on conservation and where evidence has been found, the effects are only local. Furthermore, PES contracts are always time limited despite the fact that conservation needs a much longer time frame. The success of the conservation project depends on the willingness of a buyer to pay again for the ES - turning conservation into a cost-benefit decision (Utilitarianism).

According to Gudynas (2012), an approach is possible that departs from the utilitarianism perspective and recognises alternative values of nature including, ecological, cultural, religious etc. Gudynas (2015) also stresses that nature cannot be valued one-dimensionally (economically), and that price is only one indicator amongst many.

I argue thatGreen economy takes an anthropocentric perspective, which is also the case for traditional western views of development and progress. This anthropocentric perspective not only centres on humans, but also implies that humans are separate from nature. In comparison, by adopting the intrinsic value perspective, we acknowledge that nature has its own place within human societies, like humans will have its place within nature's organisation. Humans and nature are not separated.

To put it simply, in a Green Economy scenario there is recognition of nature and its intrinsic value somewhat. However, when applying an economic or one-dimensional approach in putting a value on nature the outcome is wholly anthropocentric as it to ensure a nature base for future generations and that nature base is to ensure further development; economic development. The environmental ethical complication here is that in this anthropocentric approach to preserve nature for future generations, there is a disregard to ensure a nature base for nature and other forms of living species, therefore conflicting with eco-centric, bio-centric, among other ethical theories of environmental ethics.

So the question remains, what environmental ethical camp does Green Economy lay in? If we take the definition of eco-centrism by MacKinnon (2007, p.336) stating it is non-human centred and recognising a nature-centred system of values, and extends the inherent worth to all living things regardless of their usefulness to humans, we can rule out that Green Economy takes this approach as Green Economy's preservation of nature is to serve humans and future human generations.

What about Deep Ecology theory? Naess (1973) defines Deep Ecology as encompassing both anthropocentric and eco-centric reasoning by acknowledging intrinsic value in all nature's beings and allowing for consuming species to benefit from what the environment offers to fulfil vital needs. At first glance, this environmental ethical theory can very well fit the criteria of Green Economy, however if we focus on the key words of vital needs and apposed to wants or luxuries then we find another complication for an ethical fit for Green Economy. The assumption that human-welfare will accept a livelihood based on only utilizing nature and its resources for basic survival needs and not wants for a more materialistic and leisurely lifestyle is highly unlikely.

\section{Conclusion:-}

It is safe to conclude that a Green Economy approach implies a certain level of environmental ethics that form one path to sustainable development. However, it also encompasses traditional and anthropocentric ethical theories that seem to take precedence. It seems clear that Green Economy takes a little from each of the ethical pies, a little utilitarianism and deontology as well as a little eco-centrism and a little deep ecology to form a hybrid ethical foundation in which a Green Economy paradigm can achieve a pathway to sustainable development.

As mentioned before, this paper is not to discredit Green Economic approaches and transitions. Rather,it is to address the axiomatic assumption that a Green Economic paradigm applies wholly environmental ethical principles 
and value systems that align to solve the global issues of environmental degradation and exploitation is somewhat misled. Many more questions arise after the enquiries of this paper, such as, is it possible for any economic paradigm to wholly encapsulate and apply environmental ethics as per their definitions. After all, economy as we know it is about economic development and progress mostly at the expense of natural resource utilisation. Another question being does the notion of sustainable development allow for applied environmental ethics to be considered? If taking the anthropocentric definition of serving current and future generations with a nature capital base allowing for further and future economic development; then conflicts also arise to make room for environmental ethics to thrive in its full capacity.

\section{References:-}

1. Barbier, E.B., Markandya, A. and Pearce, D.W. (1990) Environmental sustainability and cost-benefit analysis. Environment and Planning, 22, 1269-76.

2. Blowers, A. and Hinchcliffe, S. (2003). Environmental Responses. John Wiley and Sons, Chichester. The Open University, UK.

3. Dawson, G. (2003) 'Environmental sustainability' in Economics and Economic Change: Macroeconomics. Milton Keynes, The Open University.

4. Ervine, K. (2011). Conservation and conflict: the intensification of property rights disputes under market-based conservation in Chiapas, México. Journal of Political Ecology, 18: 66-80.

5. Gudynas, E. (2011). Los derechos de la Naturaleza en serio. In: La Naturaleza con derechos. De la filosofía a la práctica. A. Acosta y E. Martínez, (Eds)., pp. 239-286. Quito, Ecuador.

6. Gudynas, E. (2015). La ecologíapolítica del girobiocéntrico en la nuevaConstitución de Ecuador. RevistaEstudiosSociales, 32: 34-47. Colombia.

7. Hargrove, C. (1992) Weak Anthropocentric Intrinsic Value. The Monist, 75: 183-207.

8. Kortetmäki, T. (2013). Anthropocentrism versus Ecocentrism Revisited: Theoretical Confusions and Practical Conclusions. SATS: Northern European Journal of Philosophy, 14 (1), 21-37. doi:10.1515/sats-2013-0002

9. MacKinnon, B (2007). Ethics: Theory and Contemporary Issues, ( $\left.5^{\text {th }} \mathrm{edn}\right)$, Thomson/Wadsworth, Belmont , California

10. Naess, A (1973). 'The Shallow and The Deep, Long-Range Ecology Movements: A summary', Inquiry, 16, pp. 95-100

11. Oak, M (2011). What is Environmental Ethics?Buzzle,viewed 25 $5^{\text {th }}$ December 2015, http://www.buzzle.com/articles/what-is-environmental-ethics.html

12. Pearce, D.W. Markandya, A. and Barbier, E.B. (1989) Blueprint for a Green Economy, Earthscan, London.

13. Pearce, D.W., and Turner RK. (1990) Economics of Natural Resources and the Environment, Harvester Wheatsheaf, Hemel Hempstead and London.

14. Turner, RK. (1988) Wetland conservation: economics and ethics, in Economics,

15. Growth and Sustainable Environments, (eds D. Collard et al.), Macmillan, London.

16. Turner, R.K., and Pearce, D.W. (1993) Economics and Ecology: New Frontiers and Sustainable Development, Netherlands, Springer.

17. Turner, R.K., Pearce, D. and Bateman, I. (1994) Environmental Economics, New York, Harvester Wheatsheaf.

18. Turner, R.K. (1999) Valuing Environmental Preferences: Theory and Practice of the Contingent Valuation Method in the US, EU and Developing Countries. Oxford, University Press.

19. UNEP (2010) Green Economy Developing Countries Success Stories. UNEP, Geneva

20. UNEP (2011) Towards a Green Economy: Pathways to Sustainable Development and Poverty Eradication. UNEP, Geneva

21. World Commission on Environment and Development (1987) Our Common Future, Oxford University Press, Oxford.

22. YONGSEN, L (2015). Environmental Ethics: Theory and Application part III, from Environmental Ethics 2050141 Environmental Ethics. Tongji University, Mingjing building on $19^{\text {th }}$ November.

23. ZHANG, J (2015). Environmental Ethics, from Environmental Ethics 2050141 Environmental Ethics. Tongji University, Mingjing building on $17^{\text {th }}$ September. 